\title{
Solvent Dependent Structural and Dynamical Properties of Elastin Mimetic Peptide [LGGVG] 3
}

\author{
Cheng SUN ${ }^{1,2 *}$ \\ ${ }^{1}$ College of Physical Science and Technology, Dalian University, Dalian, 116622, China \\ ${ }^{2}$ Liaoning Engineering Laboratory of Optoelectronic Information Technology, Dalian, 116622, China \\ crossref $\mathrm{http}: / / \mathrm{dx}$.doi.org/10.5755/j01.ms.24.3.18840
}

Received 17 August 2017; accepted 15 November 2017

\begin{abstract}
We report on the structural and dynamical properties of an elastin mimetic peptide [LGGVG] 3 under a variety of solvent environments via molecular dynamics simulation. The simulations are performed when the peptide is respectively mixed with pure water, methanol, ethanol, 1-propanol, dimethyl sulphoxide, acetone, benzene and toluene, as well as ureawater solutions. The pure solvent results indicate that the structures and dynamics of the peptide appear to be correlated to the polarity of the solvent molecules. The urea solution findings reveal that the peptide's structures and dynamics depend on the urea concentration of the solutions. The observations in this work strengthen the understanding in the structural and dynamical behaviors of the elastin mimetic peptide in solvents. From the results, we also suggest that the scheme implemented in this work can be used in studies of other biopolymers.

Keywords: elastin mimetic peptide, [LGGVG] 3 , molecular dynamics.
\end{abstract}

\section{INTRODUCTION}

Elastin is an extracellular insoluble protein that is responsible for the remarkable elasticity of many vertebrate tissues $[1-4]$. The protein is elastic only when it is hydrated, and the origin of the elasticity has been correlated to the structures and internal chain dynamics of the protein in solutions [5-7]. Upon raising temperature, an inverse temperature transition has been observed in elastin [8]. Similar thermal properties have also been observed in short peptides. For example, circular dichroism (CD) studies of the peptides $[\mathrm{VPGVG}]_{n}$ showed that the peptides exhibited the same temperature-induced structural transitions as elastin polymers [9]. ${ }^{2} \mathrm{H}$ nuclear magnetic resonance (NMR) also revealed a thermal hysteresis in the backbone and side-chain dynamics of the peptide $[\mathrm{VPGVG}]_{3}[10]$. This observation of the similar thermal properties in short peptides has encouraged the community to focus on also the structural and dynamical properties of the peptides, in order to shed light on the properties of elastin [11-13]. Several commonly studied elastin mimetic peptides include repeating motifs of VPGVG and LGGVG, since the tandem repeats are found in the hydrophobic domains of elastin and the regions are believed to bear the source of elasticity [14]. For instance, NMR experiments indicated that the peptide [LGGVG] $]_{n}$ had structural similarities to elastin and some other elastin peptides [15]. Besides, the structure of the peptide poly[LGGVG] was characterized by CD and NMR [16], and the heterogeneity in the conformation of the peptide $[\mathrm{LGGVG}]_{6}$ was also studied by solid state ${ }^{13} \mathrm{C} \mathrm{NMR}$ $[17,18]$. In addition, the structural characterization and biological properties of the amyloidogenic elastin-like peptide $[\mathrm{VGGVG}]_{3}$ was also addressed [19]. More

\footnotetext{
${ }^{*}$ Corresponding author. Tel.: +86-411-87402712.

E-mail address: suncheng@dlu.edu.cn (C. Sun)
}

recently, the phase behavior and chain dynamics of the peptide $[\mathrm{LGGVG}]_{3}$ was investigated, and it was shown that a structural phase transition occurred around the physiological temperature, which was associated with the ferroelectricity of the elastin-like peptide [20].

Solvent dynamics, polarity and solution concentrations are known to play an important role in the elasticity and dynamical properties of elastin and its mimetic peptides $[21,22]$. For instance, experimental studies of the Young's modulus demonstrated that there was a direct correlation between elasticity and the solvent $[7,21]$. CD studies of the effect of trifluoroethanol (TFE) on elastin peptide GVG[VPGVG $]_{3}$ also indicated that a solvent matrix may form to assist hydrophobic interactions between peptide side chains, depending on the TFE concentration [23]. Besides, the effect of the calcium concentration on elastinlike polypeptides was experimentally studied [24], the dynamical properties of elastin in various solvents was investigated by deuterium double quantum filtered NMR [25], and the effects of sodium dodecyl sulfate (SDS) and TFE on elastin-like peptides $[\mathrm{VPGVG}]_{n}$ were also studied by $\mathrm{CD}[9]$.

Amongst various techniques that probe the properties of the elastin mimetic peptides, molecular dynamics (MD) simulation has shown to be a convenient, useful scheme in determining the structural and dynamical properties of the peptides. For example, MD simulations were employed on the elastin-like peptide $[\mathrm{VPGVG}]_{18}$ to investigate the dominant source of elastin's elasticity [26] and the molecular basis for the inverse temperature transition of elastin [11]. MD simulations were also performed on the elastin mimetic peptide $[\mathrm{LGGVG}]_{3,7}$ to study the inverse temperature transition and elastomeric force development of elastin [27]. In this work, MD simulations were performed on the elastin mimetic peptide $[\mathrm{LGGVG}]_{3}$ with several solvents, and the structural and dynamical 
properties of the peptide were investigated under different solvent environments.

\section{METHODS}

In this work, the MD simulations were performed using GROMACS [28]. The starting structure for all simulations was a linear chain of the peptide $[\mathrm{LGGVG}]_{3}$ and the temperature was regulated at $37^{\circ} \mathrm{C}$ using a Berendsen thermostat [29]. The peptide was terminated by the amine $\left(-\mathrm{NH}_{2}\right)$ group at the $\mathrm{N}$-terminus and the carboxyl $(-\mathrm{COOH})$ group at the $\mathrm{C}$-terminus. In the simulations, the peptide was placed in a $255.30 \mathrm{~nm}^{3}$ cubic box mixed with a variety of solvents. The OPLS-AA/L force field model [30] was used for the solvents of water, methanol, ethanol and 1-propanol, and the GROMOS96 53A6 force field model [31] was employed for dimethyl sulphoxide (DMSO), acetone, benzene and toluene, as well as ureawater solutions. For the simulations involving water, the SPC216 water model was used [32]. For urea-water solutions the molar concentration of $7 \mathrm{M}, 0.5 \mathrm{M}$ and $6.7 \mathrm{mM}$ were probed in this work. These values for the concentration were chosen so that it may mimic the real biochemical conditions where the urea concentrations are both high (i.e., $7 \mathrm{M}$ ) and low (i.e., $0.5 \mathrm{M}$ and $6.7 \mathrm{mM}$ ), which may demonstrate different effects on the properties of the peptide.

For all solvents, a time duration of 4 ns was simulated. The validity of the time duration used can be justified by the root mean square deviation (RMSD) as a function of time. As examples, Fig. 1 shows the RMSD of the $\alpha$ carbons $\left(\mathrm{C}_{\alpha}\right)$ of $[\mathrm{LGGVG}]_{3}$ with the solvents of water, 1-propanol, toluene and $7 \mathrm{M}$ urea. It is clear from Fig. 1 that the RMSD appears to reach an equilibrium value after 2 ns.

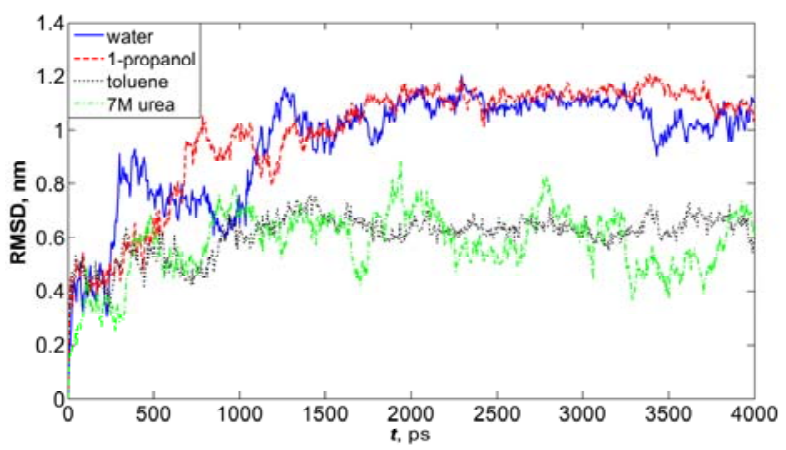

Fig. 1. RMSD averaged over all $\mathrm{C}_{\alpha}$ of $[\mathrm{LGGVG}]_{3}$ with various solvents

Similar results of the RMSD were obtained for all solvents studied indicating conformational equilibrium. In addition, the results of the simulations of [LGGVG] $]_{3}$ for 4ns was found analogous to those obtained from the simulations for $20 \mathrm{~ns}$ in Ref. [27]. It should be noted that simulations on the order of a few nanoseconds may overlook certain slow dynamical processes associated with long correlation times [33], and this is a limitation of short time MD simulation method. In all simulations, an energy minimization was first performed using the method of steepest descent to remove overlapping atoms [34], followed by short simulations restraining the peptide position and equilibrating the temperature and pressure before executing the full simulations. All data presented below in this work were averaged over the last nanosecond of the full simulation, that is, from 3 ns to $4 \mathrm{~ns}$.

\section{RESULTS AND DISCUSSION}

Simulations were first performed on the elastin mimetic peptide $[\mathrm{LGGVG}]_{3}$ solvated with water, methanol, ethanol and 1-propanol, respectively. The results averaged over the last nanosecond are summarized in Table 1.

Table 1. Results averaged from $3 \mathrm{~ns}$ to $4 \mathrm{~ns}$ of simulations for $[\mathrm{LGGVG}]_{3}$ with water, methanol, ethanol and 1-propanol. The error bars indicated by the \pm sign were determined as the standard deviation

\begin{tabular}{|c|c|c|c|c|}
\hline & Water & Methanol & Ethanol & 1-propanol \\
\hline $\mathrm{Rg}, \mathrm{nm}^{\mathrm{a}}$ & $0.61 \pm 0.03$ & $0.77 \pm 0.06$ & $0.89 \pm 0.08$ & $0.64 \pm 0.01$ \\
\hline $\begin{array}{c}\mathrm{RMSF} \\
\mathrm{nm}^{\mathrm{b}}\end{array}$ & $0.296 \pm 0.095$ & $50.208 \pm 0.095$ & $0.238 \pm 0.077$ & $0.138 \pm 0.048$ \\
\hline $\begin{array}{l}\text { SASA, } \\
\mathrm{nm}^{2} \mathrm{c}\end{array}$ & $13.1 \pm 0.5$ & $14.4 \pm 0.9$ & $15.6 \pm 0.5$ & $14.2 \pm 0.3$ \\
\hline $\begin{array}{c}\text { Non- } \\
\text { polar } \\
\text { SASA, } \\
\mathrm{nm}^{2} \mathrm{c}\end{array}$ & $8.7 \pm 0.3$ & $9.0 \pm 0.7$ & $9.7 \pm 0.4$ & $9.0 \pm 0.3$ \\
\hline $\begin{array}{c}\text { Side- } \\
\text { chain } \\
\text { contacts }^{\mathrm{d}}\end{array}$ & $49 \pm 4$ & $40 \pm 5$ & $43 \pm 6$ & $43 \pm 3$ \\
\hline $\begin{array}{l}\text { Peptide- } \\
\text { peptide } \\
\mathrm{H} \text { bonds }\end{array}$ & $2.75 \pm 1.33$ & $1.63 \pm 1.05$ & $0.11 \pm 0.34$ & $2.28 \pm 0.76$ \\
\hline $\begin{array}{c}\text { Peptide- } \\
\text { solvent } \mathrm{H} \\
\text { bonds }\end{array}$ & $27.2 \pm 3.3$ & $19.7 \pm 2.9$ & $22.1 \pm 2.5$ & $20.0 \pm 2.4$ \\
\hline $\begin{array}{c}\tau_{c} \text { of } \\
\text { peptide- } \\
\text { solvent } H \\
\text { bonds, } \\
\text { ps }^{\mathrm{f}}\end{array}$ & 1.78 & 13.0 & 34.9 & 101 \\
\hline \multicolumn{5}{|c|}{$\begin{array}{l}\text { Radius of gyration of the } \mathrm{C}_{\alpha} . \\
\text { b Root mean square fluctuation of the } \mathrm{C}_{\alpha} \text {. } \\
\text { c Solvent accessible surface area was computed with the distance } \\
\text { set to } 0.14 \mathrm{~nm} \text {. } \\
\text { d Side-chain contacts were counted when two aliphatic carbon } \\
\text { atoms were within } 0.54 \mathrm{~nm} \text { of each other, while atoms in } \\
\text { neighboring residues were not considered. } \\
\text { e Hydrogen bonds were counted when the hydrogen and the } \\
\text { acceptor were within } 0.35 \mathrm{~nm} \text { and the hydrogen bonding angle } \\
\text { was within } 30 \text {. } \\
\text { f The life time }\left(\tau_{c}\right) \text { of the peptide-solvent hydrogen bonds was } \\
\text { determined by fitting to the autocorrelation function of the } \\
\text { hydrogen bonds. }\end{array}$} \\
\hline
\end{tabular}

Table 1 highlights the physical properties of radius of gyration $(\mathrm{Rg})$ of the $\mathrm{C}_{\alpha}$ of the peptide, root mean square fluctuation (RMSF) of the $\mathrm{C}_{\alpha}$, solvent accessible surface area (SASA) of the peptide, side-chain contacts, number of hydrogen bonds formed within the peptide (labeled 
peptide-peptide $\mathrm{H}$ bonds), and the hydrogen bonds between the peptide and different solvents (labeled peptide-solvent $\mathrm{H}$ bonds) as well as its life time. The metrics that were used to evaluate the physical properties are similar to that was implemented in Ref. [11], and are detailed in the footnotes of the table.

Referring to the radius of gyration in Table 1 , the geometric size of the peptide with methanol or ethanol is larger than that with water, indicating an unfolded configuration for the peptide with methanol and with ethanol. This is consistent with the observations that the SASA and non-polar SASA in the case of methanol or ethanol are greater than the case of water, concomitant with that the number of side-chain contacts and the number of hydrogen bonds formed within the peptide are smaller for methanol or ethanol. The above observations clearly illustrate that once the peptide is solvated with pure methanol or ethanol, an unfolded structure is preferred instead of the native folded configuration of the peptide being in water.

Comparing the results for 1-propanol with those for water, it is found from Table 1 that although $\mathrm{Rg}$ and peptide-peptide $\mathrm{H}$ bonds are similar for both solvents, the SASA and side-chain contacts are different, suggesting also a variation in the structures between the two solvents. In order to further probe this, the Ramachandran plots of the valine (V) residues are shown in Fig. 2, and the detailed hydrogen bonds within the peptide are also tabulated in Table 2 for both cases of water and 1-propanol. From Fig. 2 a, it is clear that ordered structures of $\alpha$-helix and $\beta$-turn are both present in the peptide with water. The presence of these configurations is a wellknown notion in the elastin community, and it was also observed in the peptide of $[\mathrm{LGGVG}]_{3}$ with water previously [27]. However, only $\beta$-turn configuration is observed in the peptide with 1-propanol from Fig. 2 b, indicating a difference in the preferential structures between the two solvents. The result shown in Fig. 2 is in good agreement with the hydrogen bond numbers given in Table 2, where the zero value for the $n+4 \rightarrow n$ peptidepeptide hydrogen bonds in the case of 1-propanol accounts for the absence of $\alpha$-helix in the corresponding Ramachandran plot. The results from Fig. 2 and Table 2, together with the larger SASA and smaller side-chain contacts revealed in Table 1 for 1-propanol, indicate that the peptide becomes less ordered once it is solvated with 1propanol than that with water.
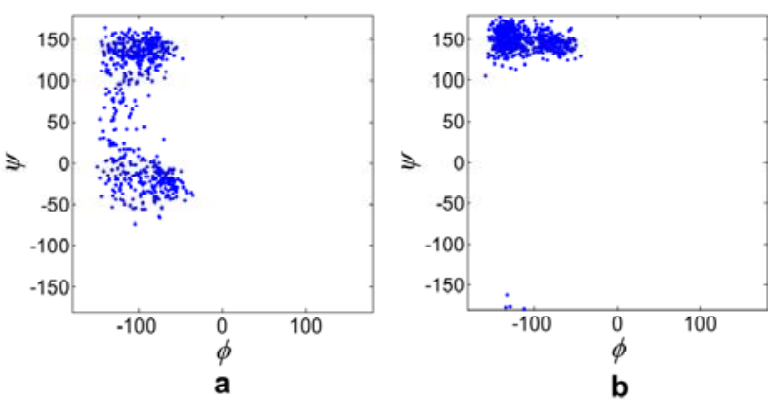

Fig. 2. Valine Ramachandran plots computed from 3 ns to 4 ns of simulations for $[\mathrm{LGGVG}]_{3}$ : $\mathrm{a}$-with water; $\mathrm{b}$-with 1-propanol
Table 2. $n+3 \rightarrow n$ and $n+4 \rightarrow n$ peptide-peptide hydrogen bonds averaged from $3 \mathrm{~ns}$ to $4 \mathrm{~ns}$ of simulations for $[\mathrm{LGGVG}]_{3}$ with water and 1-propanol. The error bars indicated by the \pm sign were determined as the standard deviation

\begin{tabular}{|c|c|c|}
\hline & Water & 1-propanol \\
\hline$n+3 \rightarrow n^{\mathrm{a}}$ & $0.73 \pm 0.75$ & $0.78 \pm 0.41$ \\
\hline$n+4 \rightarrow n^{\mathrm{a}}$ & $0.62 \pm 0.54$ & 0 \\
\hline
\end{tabular}

${ }^{a}$ Hydrogen bonds were counted when the hydrogen and the acceptor were within $0.35 \mathrm{~nm}$ and the hydrogen bonding angle was within $30^{\circ}$.

Table 1 also shows the numbers of the peptide-solvent hydrogen bonds. Note that this is merely to show the presence of the hydrogen bonds between the peptide and different solvents, and given that the solvent molecules are different, it is not so meaningful to laterally compare the absolute values among the solvents. From the hydrogen bonds at any given time $t$, the autocorrelation function of all $\mathrm{H}$ bonds can be computed by,

$\mathrm{C}(\tau)=<s_{i}(t) s_{i}(t+\tau)>$

where $s_{i}(t)=[0,1]$ for $\mathrm{H}$ bond $i$ at time $t$. The corresponding autocorrelation functions for the peptidesolvent hydrogen bonds are plotted in Fig. 3 for the solvents of water, methanol, ethanol and 1-propanol.

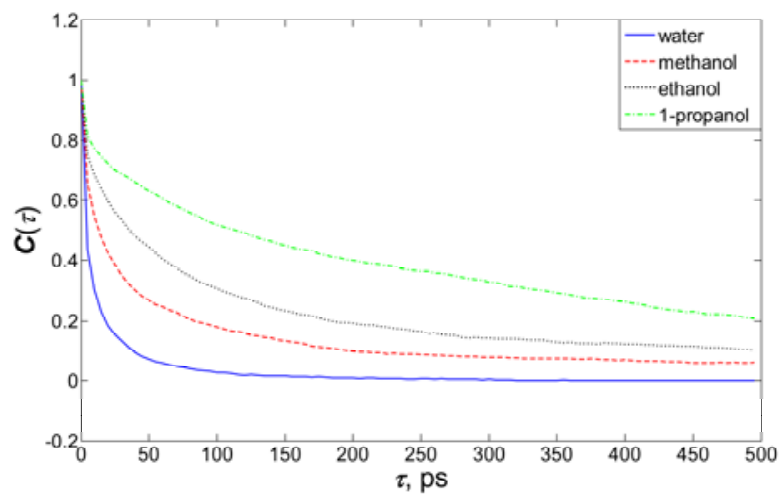

Fig. 3. Autocorrelation functions for the peptide-solvent hydrogen bonds, computed from 3 ns to 4 ns of simulations for $[\mathrm{LGGVG}]_{3}$ with water, methanol, ethanol and 1-propanol

By fitting the autocorrelation functions using multiexponential fits detailed in Ref. [35], the $\mathrm{H}$ bond lifetimes $\tau_{c}$ were obtained, and are also tabulated in Table 1. Referring again to Table 1, the life time of the peptidesolvent hydrogen bonds is increased as the size of the solvent molecule increases from water to 1-propanol. The increase in the life time may therefore be attributed to the decrease in the tumbling motion of the solvent molecules, as the molecular size increases from water to 1-propanol. Besides, the $\alpha$ carbon RMSFs of the peptide with methanol, ethanol and 1-propanol are observed to be smaller than that with water, highlighting a less mobile dynamics of the peptide solvated with the former three solvents than that with water. This is strong evidence that the dynamics of the elastin backbone is correlated with the dynamics of the solvents, which was also reported in Ref. [36] wherein the water dynamics was found to play a crucial role in the elasticity of elastin by NMR. In this 
work, because the peptide is correlated with the methanol, ethanol or 1-propanol molecules for longer time (indicated by the life time) and meantime the three solvent molecules undergo slower motions than water, the mobility of the peptide is restrained by either of the three solvents, giving rise to smaller values for the RMSF than that for water. Next set of simulations were carried out on the peptide $[\mathrm{LGGVG}]_{3}$ solvated with other commonly encountered solvents including dimethyl sulphoxide (DMSO), acetone, benzene and toluene. The average values of the peptide properties were also computed over the last nanosecond, and are tabulated in Table 3.

Table 3. Results averaged from $3 \mathrm{~ns}$ to $4 \mathrm{~ns}$ of simulations for $[\mathrm{LGGVG}]_{3}$ with DMSO, acetone, benzene and toluene. The error bars indicated by the \pm sign were determined as the standard deviation

\begin{tabular}{|c|c|c|c|c|}
\hline & DMSO & Acetone & Benzene & Toluene \\
\hline $\mathrm{Rg}, \mathrm{nm}^{\mathrm{a}}$ & $1.05 \pm 0.05$ & $0.78 \pm 0.03$ & $1.19 \pm 0.04$ & $0.89 \pm 0.04$ \\
\hline $\begin{array}{c}\text { RMSF, } \\
\mathrm{nm}^{\mathrm{b}}\end{array}$ & $0.187 \pm 0.045$ & $0.270 \pm 0.080$ & $0.161 \pm 0.061$ & $0.192 \pm 0.049$ \\
\hline $\begin{array}{l}\text { SASA, } \\
\mathrm{nm}^{2 \mathrm{c}}\end{array}$ & $16.3 \pm 0.3$ & $16.5 \pm 0.3$ & $15.2 \pm 0.4$ & $14.2 \pm 0.4$ \\
\hline $\begin{array}{c}\text { Non- } \\
\text { Polar } \\
\text { SASA, } \\
\mathrm{nm}^{2 \mathrm{c}}\end{array}$ & $10.0 \pm 0.3$ & $9.9 \pm 0.2$ & $9.8 \pm 0.3$ & $9.7 \pm 0.2$ \\
\hline $\begin{array}{c}\text { Polar } \\
\text { SASA, } \\
\mathrm{nm}^{2 \mathrm{c}}\end{array}$ & $6.4 \pm 0.2$ & $6.6 \pm 0.2$ & $5.4 \pm 0.3$ & $4.6 \pm 0.3$ \\
\hline $\begin{array}{c}\text { Side- } \\
\text { chain } \\
\text { contacts }^{\mathrm{d}}\end{array}$ & $36 \pm 3$ & $37 \pm 2$ & $34 \pm 1$ & $37 \pm 2$ \\
\hline $\begin{array}{l}\text { Peptide- } \\
\text { peptide } \\
\mathrm{H} \text { bonds }\end{array}$ & $0.60 \pm 0.66$ & $0.01 \pm 0.12$ & $5.04 \pm 1.68$ & $6.14 \pm 1.42$ \\
\hline $\begin{array}{c}\text { Peptide- } \\
\text { solvent } \mathrm{H} \\
\text { bonds }^{\mathrm{e}}\end{array}$ & $14.3 \pm 1.0$ & $16.6 \pm 0.6$ & 0 & 0 \\
\hline $\begin{array}{c}\tau_{c} \text { of } \\
\text { peptide- } \\
\text { solvent } H \\
\text { bonds, } \\
\text { ps }^{\mathrm{f}}\end{array}$ & 431 & 583 & - & - \\
\hline \multicolumn{5}{|c|}{$\begin{array}{l}{ }^{a} \text { Radius of gyration of the } \mathrm{C}_{\alpha .} \\
\text { b } \\
{ }^{\mathrm{c}} \text { Root mean square fluctuation of the } \mathrm{C}_{\alpha} \text {. } \\
\text { c Solvent accessible surface area was computed with the distance } \\
\text { set to } 0.14 \mathrm{~nm} \text {. } \\
\text { d Side-chain contacts were counted when two aliphatic carbon } \\
\text { atoms were within } 0.54 \mathrm{~nm} \text { of each other, while atoms in } \\
\text { neighboring residues were not considered. } \\
\text { e Hydrogen bonds were counted when the hydrogen and the } \\
\text { acceptor were within } 0.35 \mathrm{~nm} \text { and the hydrogen bonding angle } \\
\text { was within } 30^{\circ} \text {. } \\
\text { f The life time }\left(\tau_{c}\right) \text { of the peptide-solvent hydrogen bonds was } \\
\text { determined by fitting to the autocorrelation function of the } \\
\text { hydrogen bonds. }\end{array}$} \\
\hline
\end{tabular}

By comparing the properties shown in Table 3 with the case of water given in Table 1, it is found that for all solvents studied in Table 3 the Rg and SASA are greater as well as the side-chain contacts are smaller than those for water. This demonstrates that the peptide is in an unfolded structure once it is solvated with either DMSO, acetone, benzene or toluene. In addition, the RMSF for all the solvents are observed to be smaller than that for water, indicating a reduction in the mobility of the peptide with these solvents. Further, by carefully examining Table 3 two other interesting features are also witnessed. One is that the life times of the peptide-solvent hydrogen bonds are much longer for DMSO and acetone (i.e., $431 \mathrm{ps}$ and $583 \mathrm{ps}$ ), compared with that for water (i.e., $1.78 \mathrm{ps}$ ). This may be due to a combination of (a) the stable interaction between the peptide and the solvent molecules and (b) the relatively slow tumbling motions of the solvent molecules. The stable interaction between peptide and solvent is also revealed by the numbers of the hydrogen bonds shown in Table 3, where the hydrogen bonds formed between peptide and solvent are much greater than that formed within the peptide for both DMSO and acetone.

The other feature is the observation that the number of the peptide-peptide hydrogen bonds for both benzene and toluene are large and even greater than that for water (shown in Table 1). This is attributed to the polarity of the solvent molecules. Note that the solvent polarity may be quantified by the dielectric constant $(\varepsilon)$ of the solvent molecules, and the polarities of benzene and toluene are much weaker than those of DMSO and acetone (i.e, $\varepsilon=2.3$ for benzene and 2.4 for toluene, while $\varepsilon=49$ for DMSO and 21 for acetone at room temperature). Because the polarities of benzene and toluene are weak and no apparent $\mathrm{H}$ donor or acceptor groups exist in either benzene or toluene, there is no hydrogen bonding between the peptide and the solvent molecules, which manifests itself into the zero values for the peptide-solvent $\mathrm{H}$ bonds as indicated in Table 3. In contrast to the case of DMSO and acetone wherein the polar sites of the peptide are attracted by the much polar solvent molecules, giving rise to few chances for the peptide to form hydrogen bonds within itself, the less polar benzene and toluene molecules are not so attractive to the peptide, or rather even repel the peptide; this is indicated by the reduction in the polar solvent accessible surface area with respect to those for DMSO and acetone, as shown in Table 3. Therefore, the peptide tends to form more hydrogen bonds within itself in the circumstances of benzene or toluene, resulting in even greater values for the peptide-peptide $\mathrm{H}$ bonds than that for water. Further, the valine Ramachandran plots of the peptide with benzene and toluene is shown in Fig. 4, highlighting a difference in the favorable structures for the peptide with benzene and toluene from that with water (indicated in Fig. 2 a).
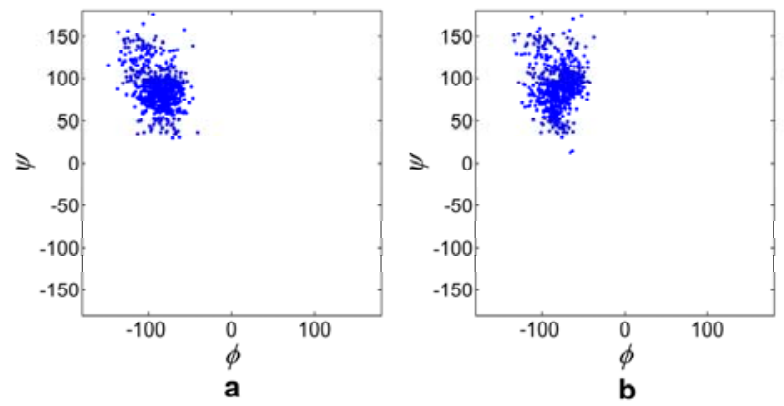

Fig. 4. Valine Ramachandran plots computed from $3 \mathrm{~ns}$ to $4 \mathrm{~ns}$ of simulations for $[\mathrm{LGGVG}]_{3}$ : $\mathrm{a}$ - with benzene; $\mathrm{b}$ - toluene

Based on more detailed calculations of the hydrogen bonds within the peptide, it is determined that the $n+4 \rightarrow n$ 
and $n+3 \rightarrow n \mathrm{H}$ bonds, which are indicative of $\alpha$-helices and $\beta$-turns, occupy almost $49 \%$ of the total peptide-peptide $\mathrm{H}$ bonds for water, while the proportion is only $13 \%$ for benzene and $26 \%$ for toluene. These numbers together with the Ramachandran plots shown in Fig. 4 clearly demonstrate that the favorable structures of the peptide with benzene or toluene are dramatically different from that with water.

Lastly, the peptide $[\mathrm{LGGVG}]_{3}$ with urea-water solutions was also simulated, and the molar concentrations of the urea solutions were $7 \mathrm{M}, 0.5 \mathrm{M}$ and $6.7 \mathrm{mM}$, respectively. The values for the physical properties of the peptide were also determined by averaging over the last nanosecond, and the results are given in Table 4. It is evident from Table 4 that the two solutions with low concentrations of $0.5 \mathrm{M}$ and $6.7 \mathrm{mM}$ both give rise to the characteristics of the peptide that is very similar to the case of water (shown in Table 1).

Table 4. Results averaged from $3 \mathrm{~ns}$ to $4 \mathrm{~ns}$ of simulations for $[\mathrm{LGGVG}]_{3}$ with urea-water solutions, and the molar concentrations were $7 \mathrm{M}, 0.5 \mathrm{M}$ and $6.7 \mathrm{mM}$. The error bars indicated by the \pm sign were determined as the standard deviation.

\begin{tabular}{|c|c|c|c|}
\hline & $7 \mathrm{M}$ urea & $0.5 \mathrm{M}$ urea & $6.7 \mathrm{mM}$ urea \\
\hline $\mathrm{Rg}, \mathrm{nm}^{\mathrm{a}}$ & $1.07 \pm 0.08$ & $0.60 \pm 0.04$ & $0.6 \pm 0.03$ \\
\hline RMSF, $n^{b}$ & $0.265 \pm 0.061$ & $0.267 \pm 0.054$ & $0.232 \pm 0.082$ \\
\hline SASA, $\mathrm{nm}^{2 \mathrm{c}}$ & $16.1 \pm 0.5$ & $12.5 \pm 0.6$ & $12.7 \pm 0.6$ \\
\hline $\begin{array}{c}\text { Non-polar } \\
\text { SASA, } \mathrm{nm}^{2 \mathrm{c}}\end{array}$ & $9.8 \pm 0.3$ & $8.2 \pm 0.4$ & $8.2 \pm 0.4$ \\
\hline $\begin{array}{c}\text { Side-chain } \\
\text { contacts }^{\mathrm{d}}\end{array}$ & $36 \pm 3$ & $48 \pm 4$ & $47 \pm 6$ \\
\hline $\begin{array}{l}\text { Peptide- } \\
\text { peptide } \mathrm{H} \\
\text { bonds }^{\mathrm{e}}\end{array}$ & $0.17 \pm 0.39$ & $2.80 \pm 1.51$ & $2.67 \pm 1.09$ \\
\hline $\begin{array}{c}\text { Peptide-water } \\
\text { H bonds }\end{array}$ & $19.2 \pm 3.4$ & $23.9 \pm 3.1$ & $25.5 \pm 3.0$ \\
\hline $\begin{array}{l}\text { Peptide-urea } \mathrm{H} \\
\text { bonds }\end{array}$ & $10.7 \pm 3.1$ & $0.45 \pm 0.79$ & 0 \\
\hline $\begin{array}{c}\tau_{c} \text { of peptide- } \\
\text { urea } \mathrm{H} \text { bonds, } \\
\mathrm{ps}^{\mathrm{f}}\end{array}$ & 36.0 & 12.6 & - \\
\hline \multicolumn{4}{|c|}{$\begin{array}{l}\text { a Radius of gyration of the } \mathrm{C}_{\alpha} \text {. } \\
{ }^{\mathrm{b}} \text { Root mean square fluctuation of the } \mathrm{C} \alpha \text {. } \\
{ }^{\mathrm{c}} \text { Solvent accessible surface area was computed with the distance } \\
\text { set to } 0.14 \mathrm{~nm} \text {. } \\
\text { d Side-chain contacts were counted when two aliphatic carbon } \\
\text { atoms were within } 0.54 \mathrm{~nm} \text { of each other, while atoms in } \\
\text { neighboring residues were not considered. } \\
{ }^{\mathrm{e}} \text { Hydrogen bonds were counted when the hydrogen and the } \\
\text { acceptor were within } 0.35 \mathrm{~nm} \text { and the hydrogen bonding angle } \\
\text { was within } 30^{\circ} \text {. } \\
{ }^{\mathrm{f}} \text { The life time }\left(\tau_{c}\right) \text { of the peptide-urea hydrogen bonds was } \\
\text { determined by fitting to the autocorrelation function of the } \\
\text { hydrogen bonds. }\end{array}$} \\
\hline
\end{tabular}

For example, the Rg, SASA, non-polar SASA, sidechain contacts and peptide-peptide $\mathrm{H}$ bonds for both $0.5 \mathrm{M}$ and $6.7 \mathrm{mM}$ urea are almost identical to the corresponding properties for water, indicating a similar structure of the peptide with low concentration urea-water solutions to that with pure water. This clearly shows that the effect of the presence of urea on the structural properties of the peptide is little at low concentration. While the dynamics of the peptide is varied by the presence of urea from pure water, as indicated by the RMSF for $0.5 \mathrm{M}$ and $6.7 \mathrm{mM}$ urea shown in Table 4. It is also clear from Table 4 that almost every property of the high concentration solution of $7 \mathrm{M}$ urea is different from that of the low concentration solutions of $0.5 \mathrm{M}$ and $6.7 \mathrm{mM}$ urea. For $7 \mathrm{M}$ urea, the greater values of $\mathrm{Rg}$, SASA and non-polar SASA, concomitant with the smaller values of the side-chain contacts and peptide-peptide $\mathrm{H}$ bonds, reveal an unfolded structure of the peptide with a urea concentration as high as $7 \mathrm{M}$. This finding is in good agreement with the known notion in the protein community that the urea solution with a molar concentration of 4-7 M can cause an unfolding of the protein. Once the urea concentration is decreased the effect of the urea on the structural unfolding weakens, and this is well illustrated by the Ramachandran plots as shown in Fig. 5. Fig. 5 highlights that as the urea concentration is decreased from $7 \mathrm{M}$ to $6.7 \mathrm{mM}$, the structure of the peptide with urea-water solutions becomes similar to that with pure water. Referring back to Table 4, with decreasing the concentration of the urea solutions, it is also observed that the number of the peptide-urea hydrogen bonds is decreased, together with that the number of the peptidewater hydrogen bonds is increased. This is obvious evidence that the introduction of the urea molecules would interrupt the interaction between peptide and water molecules, by forming new hydrogen bonds between peptide and urea molecules. This notion also correlates well to the values of the peptide-urea $\mathrm{H}$ bond life times indicated in Table 4 wherein the higher urea concentration (i.e., $7 \mathrm{M}$ ) results in a longer life time $\tau_{c}$, suggesting a more stable interaction between the peptide and urea molecules.
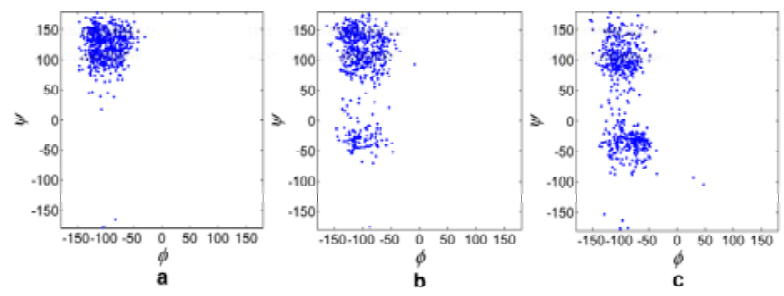

Fig. 5. Valine Ramachandran plots computed from 3 ns to 4 ns of simulations for $[\mathrm{LGGVG}]_{3}$ with urea-water solutions of: $\mathrm{a}-7 \mathrm{M} ; \mathrm{b}-0.5 \mathrm{M} ; \mathrm{c}-6.7 \mathrm{mM}$

\section{CONCLUSIONS}

In this work, we have performed molecular dynamics simulations on the elastin mimetic peptide $[\mathrm{LGGVG}]_{3}$ solvated with a variety of solvents including pure water, methanol, ethanol, 1-propanol, DMSO, acetone, benzene and toluene, as well as urea-water solutions. The solvent dependent structural and dynamical properties of the peptide have been examined. The results of the pure solvent studies have shown that the structures and dynamics of the peptide are correlated to the polarity of the solvent molecules, through the interaction between the peptide and the solvent molecules. The findings of the urea solutions demonstrate the effects of the solution concentration on the peptide's structures and dynamics. The observations made in this work extend the understanding of the structural and dynamical behaviours of the elastin mimetic peptide in the solvents. From the 
results, we also suggest that the scheme implemented in this work be used in studies of other biopolymers.

\section{Acknowledgments}

C. Sun acknowledges support by Grant Number 31400718 from the National Natural Science Foundation of China.

\section{REFERENCES}

1. Hoeve, C.A.J., Flory, P.J. The Elastic Properties of Elastin Journal of the American Chemical Society 80 1958: pp. $6523-6526$. https://doi.org/10.1021/ja01557a016

2. Hoeve, C.A.J., Flory, P.J. The Elastic Properties of Elastin Biopolymers 23 1974: pp. 677-686.

3. Gray, W.R., Sandberg, L.B., Foster, J.A. Molecular Model for Elastin Structure and Function Nature 246 1973: pp. $461-466$.

4. Dorrington, K., Grut, W., McCrum, N.G. Mechanical State of Elastin Nature 255 1975: pp. 476-478.

5. Weis-Fogh, T., Andersen, S.O. New Molecular Model for the Long-Range Elasticity of Elastin Nature 227 1970: pp. $718-721$.

6. Urry, D.W., Parker, T.M. Mechanics of Elastin: Molecular Mechanism of Biological Elasticity and Its Relationship to Contraction Journal of Muscle Research and Cell Motility 23 2002: pp. $543-559$. https://doi.org/10.1007/978-94-010-0147-2_14

7. Mistrali, F., Volpin, D., Garibaldo, G.B., Ciferri, A. Thermodynamics of Elasticity in Open Systems: Elastin Journal of Physical Chemistry 75 1971: pp. $142-150$. https://doi.org/10.1021/j100671a023

8. Urry, D.W. Entropic Elastic Processes in Protein Mechanisms. I. Elastic Structure Due to an Inverse Temperature Transition and Elasticity Due to Internal Chain Dynamics Journal of Protein Chemistry 7 1988: pp. 1-34.

9. Reiersen, H., Clarke, A.R., Rees, A.R. Short Elastin-Like Peptides Exhibit the Same Temperature-Induced Structural Transitions as Elastin Polymers: Implications for Protein Engineering Journal of Molecular Biology 283 1998: pp. $255-264$. https://doi.org/10.1006/jmbi.1998.2067

10. Ma, X., Sun, C., Huang, J.X., Boutis, G.S. Thermal Hysteresis in the Backbone and Side-Chain Dynamics of the Elastin Mimetic Peptide [VPGVG] $]_{3}$ Revealed by ${ }^{2} \mathrm{H}$ NMR Journal of Physical Chemistry B 116 2012: pp. 555-564. https://doi.org/10.1021/jp208966k

11. Li, B., Alonso, D.O.V., Daggett, V. The Molecular Basis for the Inverse Temperature Transition of Elastin Journal of Molecular Biology 305 2001: pp. 581-592. https://doi.org/10.1006/jmbi.2000.4306

12. Miao, J., Klein-Seetharamanmx-Seetharaman, J., Meirovitch, H. The Optimal Fraction of Hydrophobic Residues Required to Ensure Protein Collapse Journal of Molecular Biology 344 2004: pp. 797-811. https://doi.org/10.1016/j.jmb.2004.09.061

13. Schreiner, E., Nicolini, C., Ludolph, B., Ravindra, R., Otte, N., Kohlmeyer, A., Rousseau, R., Winter, R., Marx, D. Folding and Unfolding of an Elastinlike Oligopeptide: "Inverse Temperature Transition" Reentrance, and Hydrogen-Bond Dynamics Physical Review Letters 92 2004: pp. 148101.
https://doi.org/10.1103/PhysRevLett.92.148101

14. Muiznieks, L.D., Weiss, A.S., Keeley, F.W. Structural Disorder and Dynamics of Elastin Biochemistry \& Cell Biology 88 2010: pp. 239-250. https://doi.org/10.1139/o09-161

15. Kumashiro, K.K., Kurano, T.L., Niemczura, W.P., Martino, M., Tam-burro, A.M. ${ }^{13}$ C CPMAS NMR Studies of the Elastin-Like Polypeptide $(\mathrm{LGGVG})_{\mathrm{n}}$ Biopolymers 70 2003: pp. $221-226$. https://doi.org/10.1002/bip.10470

16. Martino, M., Coviello, A., Tamburro, A.M. Synthesis and Structural Characterization of Poly(LGGVG), an ElastinLike Polypeptide International Journal of Biological Macromolecules 27 2000: pp. 59-64. https://doi.org/10.1016/S0141-8130(99)00118-X

17. Ohgo, K., Niemczura, W.P., Ashida, J., Okonogi, M., Asakura, T., Kumashiro, K.K. Heterogeneity in the Conformation of Valine in the Elastin Mimetic (LGGVG) as Shown by Solid-State ${ }^{13} \mathrm{C}$ NMR Spectroscopy Biomacromolecules 7 2006: pp. 3306-3310. https://doi.org/10.1021/bm0607168

18. Kumashiro, K.K., $\quad$ Ohgo, K., Niemczura, W.P. Onizuka, A.K., Asakura, T. Structural Insights into the Elastin Mimetic (LGGVG)6 Using Solid-State ${ }^{13} \mathrm{C}$ NMR Experiments and Statistical Analysis of the PDB Biopolymers 89 2008: pp. 668-679. https://doi.org/10.1002/bip.20984.

19. Moscarelli, P., Boraldi, F., Bochicchio, B., Pepe, A. Salvi, A.M., Quaglino, D. Structural Characterization and Biological Properties of the Amyloidogenic Elastin-Like Peptide (VGGVG)3 Matrix Biology 36 2014: pp. 15-27. https://doi.org/10.1016/j.matbio.2014.03.004

20. Dandurand, J., Samouillan, V., Lacabanne, C., Pepe, A., Bochicchio, B. Phase Behavior and Chain Dynamics of Elastin-Like Peptides Versus Amino Acid Sequences Journal of Thermal Analysis and Calorimetry 2017 https://doi.org/10.1007/s10973-017-6633-5

21. Lillie, M.A., Gosline, J.M. The Effects of Polar Solutes on the Viscoelastic Behaviour of Elastin Biorheology 30 1993: pp. 229-242.

22. Lyerla, J.R.Jr., Torchia, D.A. Molecular Mobility and Structure of Elastin Deduced from the Solvent and Temperature Dependence of ${ }^{13} \mathrm{C}$ Magnetic Resonance Relaxation Data Biochemistry 14 1975: pp. 5175-5183. https://doi.org/10.1021/bi00694a024

23. Reiersen, H., Rees, A.R. Trifluorethanol May Form a Solvent Matrix for Assisted Hydrophobic Interactions Between Peptide Side Chains Protein Engineering 13 2000: pp. $739-743$. https://doi.org/10.1093/protein/13.11.739

24. Hassouneh, W., Nunalee, M.L., $\quad$ Shelton, M.C., Chilkoti, A. Calcium Binding Peptide Motifs from Calmodulin Confer Divalent Ion Selectivity to Elastin-Like Polypeptides Biomacromolecules 14 2013: pp. $2347-2353$. https://doi.org/10.1021/bm400464s

25. Sun, C., Boutis, G.S. Investigation of the Dynamical Properties of Water in Elastin by Deuterium Double Quantum Filtered NMR Journal of Magnetic Resonance 205 2010: pp. 86-92. https://doi.org/10.1016/j.jmr.2010.04.007

26. Li, B., Alonso, D.O.V., Bennion, B.J., $\quad$ Daggett, $\mathbf{V}$. Hydrophobic Hydration is an Important Source of Elasticity in Elastin-Based Biopolymers Journal of the American Chemical Society 123 2001: pp. 11991-11998. 
https://doi.org/10.1021/ja010363e

27. Huang, J.X., Sun, C., Mitchell, O., Ng, N., Wang, Z.N., Boutis, G.S. On the Inverse Temperature Transition and Development of an Entropic Elastomeric Force of the Elastin Mimetic Peptide [LGGVG] $]_{3,7}$ Journal of Chemical Physics 136 2012: pp. 085101. https://doi.org/10.1063/1.3685454

28. Hess, B., Kutnzer, C., $\quad$ Spoel, D.V.D., $\quad$ Lindahl, E. GROMACS 4: Algorithms for Highly Efficient, LoadBalanced, and Scalable Molecular Simulation Journal of Chemical Theory and Computation 4 2008: pp. $435-447$. https://doi.org/10.1021/ct700301q

29. Berendsen, H.J.C., $\quad$ Postma, J.P.M., $\quad$ DiNola, A., Haak, J.R. Molecular Dynamics with Coupling to an External Bath Journal of Chemical Physics 81 1984: pp. $3684-3690$.

https://doi.org/10.1063/1.448118

30. Jorgensen, W.L., Tirado-Rives, J. The OPLS Force Field for Proteins. Energy Minimizations for Crystals of Cyclic Peptides and Crambin Journal of the American Chemical Society 110 1988: pp. 1657-1666. https://doi.org/10.1021/ja00214a001

31. Oostenbrink, C., Villa, A. Mark, A.E., Van Gunsteren, W.F. A Biomolecular Force Field Based on the Free Enthalpy of Hydration and Solvation: the GROMOS Force-Field Parameter Sets 53A5 and 53A6 Journal of Computational Chemistry 25 2004: pp. $1656-1676$. https://doi.org/10.1002/jcc. 20090

32. Teleman, O., Jonsson, B., Engstrom, S. A Molecular Dynamics Simulation of a Water Model with Intramolecular Degrees of Freedom Molecular Physics 60 1987: pp. $193-203$.

https://doi.org/10.1080/00268978700100141

33. Rousseau, R., Schreiner, E., Kohlmeyer, A., Marx, D. Temperature-Dependent Conformational Transitions and Hydrogen-Bond Dynamics of the Elastin-Like Octapeptide gvg(vpgvg): A Molecular Dynamics Study Biophysical Journal 86 2004: pp. 1393-1407. https://doi.org/10.1016/S0006-3495(04)74210-1

34. Zimmerman, K.J. Oral: All Purpose Molecular Mechanics Simulator and Energy Minimizer Journal of Computational Chemistry 12 1991: pp. 310-319. https://doi.org/10.1002/jcc.540120305

35. Spoel, D.V.D., Maaren, V., Larsson, P.J., Timneanu, N.P. Thermodynamics of Hydrogen Bonding in Hydrophilic and Hydrophobic Media Journal of Physical Chemistry B 110 2006: pp. $4393-4398$. https://doi.org/10.1021/jp0572535

36. Sun, C., Mitchell, O., Huang, J.X., Boutis, G.S. NMR Studies of Localized Water and Protein Backbone Dynamics in Mechanically Strained Elastin Journal of Physical Chemistry B 115 2011: pp. 13935-13942.

https://doi.org/10.1021/jp207607r 